\title{
Gender Dimension in Education: Problems and Barriers in the Process of Gender Socialization in Albanian Schools
}

\author{
Aida Zhupa, PhD Cand. \\ Teacher, Hospitality \& Tourism High School, Tirana, Albania \\ aida_zhupa@hotmail.com \\ Dr. Dorina Zenelaj \\ Lecturer, European University of Tirana \\ dorina.zenelaj@gmail.com
}

\begin{abstract}
Gender education is a major problem in Albanian schools at all levels. The proposed paper examines how various gender issues, are treated in the textbooks. Text analysis from a gender perspective, is used as method to determine the presence and treatment of gender issues in various textbooks. Admittedly, textbooks continue to play a crucial role as the basic instrument of education. Text analysis includes: text illustrations, gender stereotypes and prejudices, gender authority and leadership. On the other hand, this study, will focus on the important role of teachers which with their formation and personality, have a direct impact on students. The paper argues that every teacher should select those methods, which encourage discussion and reflection of gender situations, adapted to the cultural level and age of students. Teachers, along with textbooks should fulfill better the noble mission of education, of spiritual emancipation, material progress and the social development of students as social individuals.
\end{abstract}

Keywords: Gender Socialization, Gender Education, Text Books, Teacher's Rol.

\section{Introduction}

The role of education is essential to the social and cultural development of a democratic and advanced society. Through education, individuals have the opportunity to progress and change their economic and social status to progress in life, independently of their gender. Noëadays, it is a necessity to educate students by removing any racial, gender and cultural prejudice, to ensure solid foundations of a civil, open and global society (UNESCO 2003). The education institutions must contribute in the formation of the personality of the individuals, by creating the necessary space for the individual to overcome any hurdle or social prejudice and to build his/her future independently of the expectations of the society, family, community, etc. (Zhupa, 2014). Most of the analysis conducted by researchers in different countries is mostly centered on the influence of economic factors and socio-cultural factors, while little focus is placed on the impact of factors directly related to the school environment and educational performance - which indicate the degree in which education systems encourage and perpetuate discrimination against girls. A simple analysis of school culture, situation of textbooks and gender culture of the teachers shows that gender education at the Albanian schools of all levels has still serious issues. The educational system in Albania aims to change the schemes and models of social and cultural behaviour of boys and girls, with a view of combating prejudices, based on the concept of inferiority or superiority of either gender. They should aim at the education of students with gender roles, responsibilities and duties, notwithstanding their gender task (ISHA, 2013: 12). 


\section{Literature Review}

\section{1. Content of textbooks and gender stereotypes}

Textbooks as instruments transmitting regular knowledge, have the potential of training students with proper concepts and gender behaviours. They are a key factor for the gender socialization of students, shown in the textbooks due to prejudices and mentalities of authors in relation to gender. Text analyses have identified hidden messages that textbooks transmit to students in terms of gender behaviours. The implied content of textbooks may create and reinforce gender stereotypes through literary parts and illustrations, situations they bring for the concrete situation, gender-oriented language etc. This occurs because each of the students is identified with the roles brought to the text, reinforcing the beliefs and opinions previously formed and by organizing the provisions for the place they will represent in the society in future. If texts did not introduce typical feminine and masculine roles, the students would find themselves in the desired professions, regardless of their role. The text should encourage the students to be oriented to new social roles by respecting each other's choices and desires for broader opportunities and new experiences. The aptness to introduce stereotyped, traditional gender roles is a general trend in the Albanian textbooks. Women are generally introduced in a household setting, taking care of the cleanliness, food or care for their children and other family members, while fathers have decision-making positions, to be successful in their profession and in the society. Also, girls are attached care-based roles both within and out of home, while boys are active, involved in sports or other social activities (Sinani et al., 2008). These schemes built by the society and embedded across the centuries, influence the students' perceptions and individual approaches by educating wrong models of gender behaviour and perpetuating women's and girls' discrimination. Indeed, typical gender roles in textbooks harm both genders: girls should always have submissive, dependent roles while boys must be seen as initiators and with strong personality, deprived of the manifestation of behaviours and human emotions, which may be regarded as weaknesses. In this way, both boys and girls are forced to behave as the others expect them to behave, being deprived to be themselves and to be free to express what they really feel. It commonly appears that boys are seen in management positions, undertake initiatives and manage situations (Dhamo et.al, 2005). If girls and boys at school learned different models of behaviour from their daily experience, it would be possible to overcome gender stereotypes instilled within the family and in the society. In fact, the opposite occurs. Instead of helping the student be oriented and properly act in different real situations, textbooks are often not linked with this reality by introducing characters and topics far from real interests and problems. This is so obvious that there is often a need to check the year of publication because it appears as if the authors refer to students at another time and in another place (Dhamo et.al, 2005). The problem persists with the role played by teacher and his obligation not only to convey the text to the student, but also to identify gender-oriented problems of the textbooks. In fact, teachers are those who bring the textbook and syllabus to their students through their own world outlooks (Vu 2008). Experience shows that every teacher applies the textbooks in his/her own way. He/she interprets the purposes of the authors of textbooks through his/her own models of gender relations and identities (Sunderland, 2006). A professionally capable and responsible teacher in his work as educator should further develop the textbooks by filling the potential gaps of textbooks. Many texts lack a balanced representation of both genders, thus imposing the obligation that the teacher identifies cases of gender distortions and modalities of their manifestation, making their best efforts to reduce this flaw of textbooks (Sunderland et al. 2001: 254). Yet, there are cases when teachers hesitate to discuss with students the problems of gender prejudices identified in their textbooks. Being aware of the prevailing mentality in the society, even within the majority of students, they do not wish to debate or oppose this model of behaviour. They argue as follows: "...We cannot tell our daughters not to go out at night, equally as boys!"(Kizilaslan, 2010: 3530). The teacher, along with the textbooks, should best accomplish the noble mission of education for spiritual emancipation, material progress and social development of students as social individuals.

\section{2. Teacher-student relations and gender education process at schools}

"Sitting in the same classroom, reading the same book, listening to the same teacher, boys and girls receive a quite different education"(Sadker \& Sadker 1994). In fact, teacher-student relations are the key of success not only for an effective teaching/learning but also for the students' education on fair basis and free of prejudices. Building a good climate of cooperation and mutual respect between both genders in the classrooms favours a smooth educational process. Studies show that on a general level, the relations of teachers with girls are better and more oriented to teaching than to control and discipline, as it commonly occurs with boys. There are changes and differences in the behaviour of teachers to boys and girls. Findings from the studies on the analysis of interaction in the classroom, and of attitudes and expectations of 
teachers, have shown that boys receive more attention than girls. Apparently, boys wish to speak more often and are more confident to initiate discussions while girls are more withdrawn and wish to stay silent (Coffey \& Delamont 2000:19). The teachers orient the girls to feminine ideals. They are appreciated to be quiet and obedient, while boys are encouraged to think independently, be active and openly express themselves. The girls are educated at schools to be more social and sociable and to learn that educational performance and skills are not so important (Bailey, 1992). Indeed, in the beginnings of education the girls have equal and often better results than boys in terms of every achievement but after graduation from high school or Universities, they lag behind (Sadker \& Sadker, 1994). In an ideal classroom the boys and girls should receive equal treatment. An interesting study was conducted by the researcher Tammy A. Shel, in a gender analysis of the teaching process in respect of all internal components by comparing western and non-western countries such as: USA, Kenya, South Korea, from 1990 to 2007, and based on studies conducted in the Northern Ireland, India, Nepal, Pakistan etc. The researcher drew some important conclusions on teacher-student relations and student to student relations about prejudices in gender-related issues. Although teachers claim to treat their students on equal basis and admit the importance of gender equality in education, it is impossible for them to avoid unequal treatment of boys and girls in the classroom, thus reflecting their mentality. This often gives rise to unsatisfactory achievements in the learning process, therefore there is a striking need to cultivate and educate a climate of care and equality among the students (Shel, 2007: 9). There are also cases when teachers rather evaluate the girl students and have higher expectations for their academic achievements and boys are often seen to exhibit disruptive behaviours in classes and are really messy. However, the teacher-student interaction is mutual, which means that on their part, students bring their prejudices in the classroom. Therefore, they are more prone to listen and respect a masculine than a feminine voice (ibid., 12). The teacher/s generally pay more attention to boys, while creating larger dependency from their girl students. A number of studies show that teachers encourage girls to be more passive and conformist, while they appreciate boys' independence and individuality. In this way, they allow the boys to be "bad" considering their behaviour as quite natural, while girls should assume tasks and responsibilities like taking care of others or cleaning the classroom. They are supposed to be more cooperative and more flexible, while boys should have higher self-confidence and be more capable. Teachers maintain different attitudes in the classroom about boys and girls for the same behaviours, which is a clear manifestation of gender prejudices. Thus, for instance, a stricter attitude is adopted to girls rather than boys in cases of the breach of discipline or failure to accomplish the tasks assigned. Further, more severe punishments are imposed against boys because they can "handle" them, unlike the girls who can be emotionally moved or cry. Teachers apply more verbal punishments to girls, while boys may be removed out of classes without facing them (Shel, 2007: 10). At schools, girls are aware they are not equal to boys. When different behaviours are tolerated by the teacher, under the excuse that "boys are boys", the school has perpetuated the suppression of females (Chapman, 2009). According to Amanda Chapman (2009), girls receive from teacher/s more negative feedback than boys, especially in science subjects/modules. Favouring boys in exact sciences prevents the learning skills of girls in these fields, who have demonstrated they may learn and have equal results as boys. One of the myths created by the society is that women are quantitative, while men are qualitative, linking this with the aptness of males to exact sciences, such as mathematics, engineering and physic sciences etc, This leads to low expectations of parents, teachers and girls about their results in maths, which often creates the belief that these sciences are only for boys and they are incapable to have a career in these areas. Therefore, everyone should understand that there is no "maths gene" but practice and encouragement improves the girls' results and skills (Campbell \& Storo, 1996). High results in specific subjects/modules and areas of knowledge are often a consequence of orientations given to boys or girls by their family, circle of relatives, friends, teachers at school etc. Encouragement and skills of every student to meet his/her goal in life are main prerequisites to reach the desired goal. However, if we see our analysis from a broader perspective, this is linked with the opportunities afforded by different states about higher education and equal employment of both genders in the labour market. This would also be the sociological explanation of casual link that researchers otherwise see as a relation between the opportunity and performance. Women's status and performance depend on the opportunities the family, school, society and social policies offer them and from the level of gender discrimination of a society. AAUW Report of 1992: "How schools deceive girls" is one of the broadest and most important studies on experiences that girls and boys have in classroom. The report is based on hundreds of studies conducted and concludes that girls are at relative disadvantage in comparison to boys, although their formal education starts on equal basis. The gender gap in interests, beliefs, interactions with students and peers is increased and developed along with the students' progress (AAUW, 1992). As also stated in the AAUW report of 1998, schools should improve their strategies to enhance the girls' academic performance. In this regard, the school should attempt to create welcoming, attractive classes for girls, thus creating a cooperative and less competitive or hierarchical environment. Secondly, school may involve teachers in training, regarding it as a school obligation, in order to improve 
verbal and non-verbal communication with both genders, and methods for their equal treatment (AAUW, 1998: 68-70). The educators themselves should build safe identity premises, where girls are not felt threatened from gender stereotypes linked with potential differences and failures (Bachman et.al, 2009).

\section{Data analysis. Findings.}

The analysis of data collected through questionnaires organized with students from the general and professional high schools in Tirana during the academic year 2014-2015, has shown that most of them admitted that both textbooks and teachers had gender prejudices. This was clearly shown in the textbooks in terms of unequal representation of figures of both genders, where the dominance of boys/men was prominent both in the number of illustrations and their privileged social status compared to girls/women. Graph 1 provides the students' opinions about some of the fields where gender prejudices are displayed, in the textbooks they use at school. Accordingly, as regards the illustrations in textbooks, students admit that the figure of men/boys is more widely represented at the level of $56 \%$, in relation to $32 \%$, who have admitted that illustrations rather display the figure of woman/girl. The representation of image of both genders in the form of characters, researchers, heroes or authors studied and referred to in the textbooks is basically masculine and this is also admitted by $85 \%$ of the surveyed students. Also, the employment and decision-making in textbooks are admitted to prejudice women's role in the family, society, community, respectively at the level of $91 \%$ and $83.2 \%$. These numbers show a striking difference in the representation of both genders in textbooks, thus making their problem more sensitive.

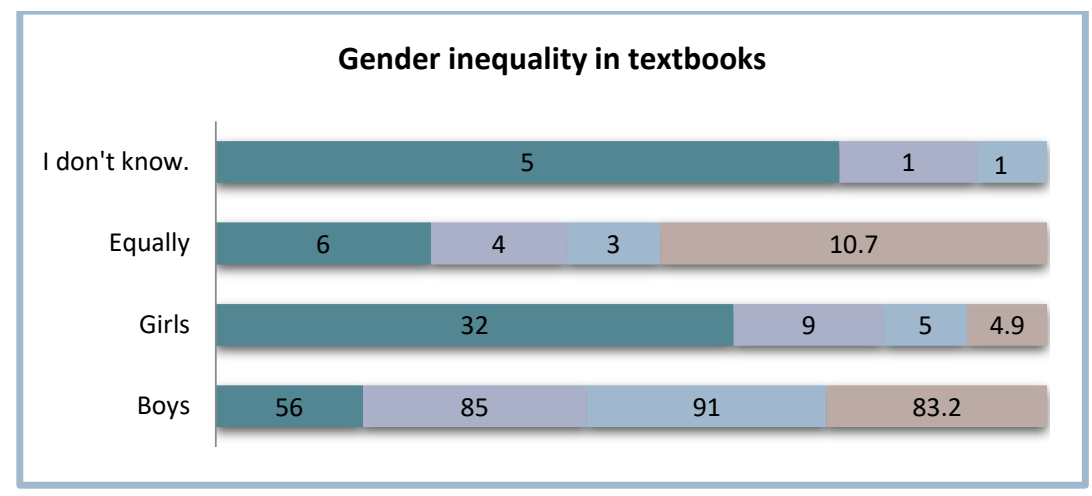

\section{Graph 1}

On the other hand, gender analysis of 60 textbooks in social sciences such as literature, social education, sociology from $\mathrm{VI}$ to XII grade, respectively in the primary and secondary education, showed a major difference in the frequency of the introduction of boys/men's figure in relation to that of women/girls and of both genders altogether. Graph 2 clearly shows the gender imbalance of illustrations in these texts.

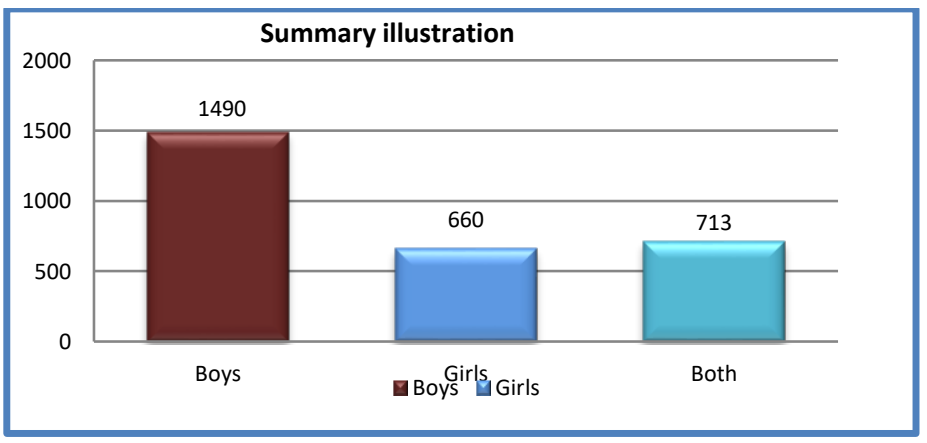

\section{Graph 2}


The figures of boys and men in relation to girls and both genders altogether are dominant at a time when the illustrating figures of both genders had to prevail, which would be associated with forums of discussions and relevant messages. Only in this way the highly important illustrating component would play its informative and educational role because it appears as if the illustrations are inserted only to fill and decorate the pages of textbooks. Further, as regards the teacher's role in gender education of the students and presence of prejudices in their behaviour, graph 3 introduces the opinions shared by students.

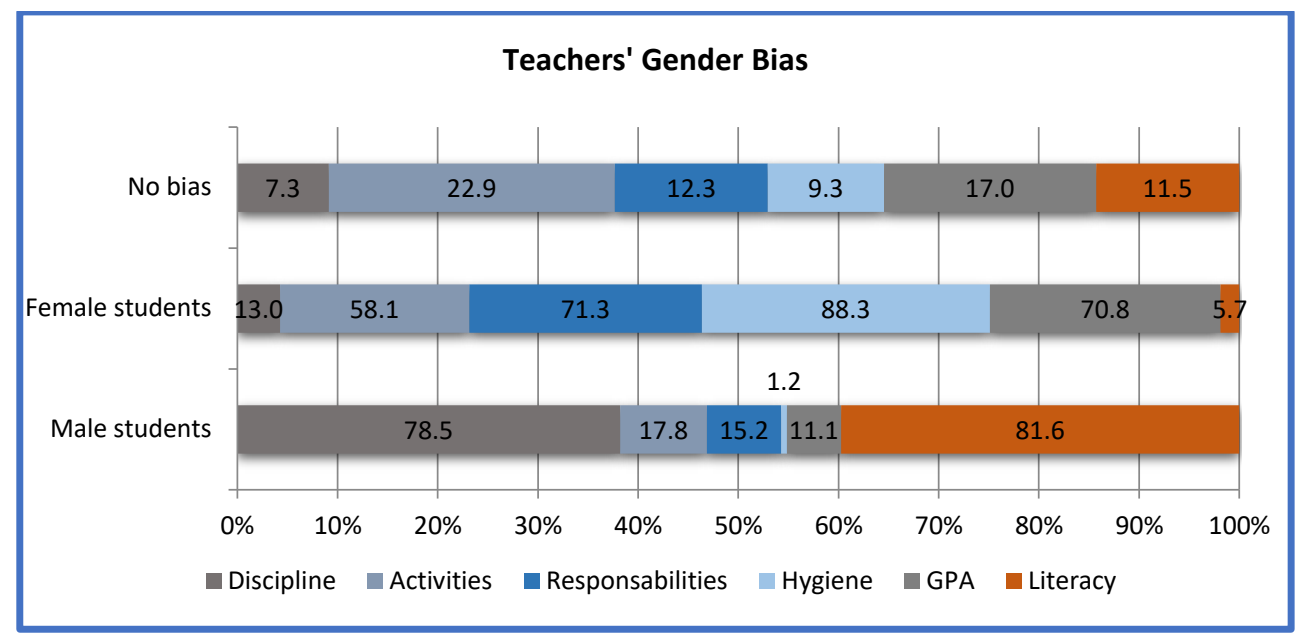

\section{Graph 3}

As shown in these graph., most of the answers of respondents reveal that boys are the most prejudiced gender by teachers, respectively, in relation to discipline at $78.5 \%$ against the gender-based language at $80 \%$; in relation to school and extracurricular activities, boys are represented by only $17.8 \%$. On the other hand, the graph shows that girls are more discriminated against the obligations and responsibilities assigned to them by teachers at the level of $71.3 \%$ in relation to the maintenance and cleaning of school premises, amounting to $88.3 \%$, but less in relation to discipline and gender prejudice language of teachers. Data collected clearly show the presence of real gender prejudices of teachers, thus attaching importance to the issue of fighting them through teacher training and awareness about gender equality issues in our education.

\section{Conclusions}

Following the whole analysis carried out above, we may conclude that gender education process at our schools should be reorganized and be focused: Firstly, on the improvement of textbooks, in particular of social subjects/modules, which should be free of prejudices and biases. The introduction of stereotyped and traditional gender roles, as well as the exclusion of life experience and achievements of women/girls in the society requires the revision of texts by specialists of gender issues in the field of education.

The non-equal involvement of both genders in textbooks makes the girls feel excluded from the models provided by the society and they risk to be passive in the future. As a result, a quicker improvement of standards and criteria is needed to be met by drafters of textbooks and publishing houses, in accordance with the international objectives of this Millennium and standards approved for the evaluation of textbooks by the Ministry of Education of year 2014. Secondly, the teacher's work and methods he/she uses in classes for a comprehensive involvement of the students without gender differences should be improved. New evaluation criteria for their work and training should be defined, in order to achieve a new European model of teachers. Based on the instructions of new educational policies, each teacher should attend compulsory training sessions regarding the training as their right and obligation, and as a responsibility of the management educational institutions and educational local units (MAS, 2014: 54). A trained teacher does not show indifference to the phenomenon of sexism at school but fights it in every aspect. Teachers are commonly seen as models wherefrom students learn. 
Therefore, it is necessary that before they teach students gender equality principles, they should change their behaviours in order to make gender equality integral part of thinking ( $\mathrm{Vu}, 2008)$. The teacher should often analyse himself/herself in relation to students during classes/modules. He/she should equally treat both genders, offering them equal time and possibility to attend classes or make questions. Both genders should be equally commended or punished by helping them move forward (Kabira \& Masinjila, 1997: 33-34).

\section{References}

[1] AAUW. (1992). How Schools Shortchange Girls. Educational Foundation. Washington, DC: 2-4, 7-8.

[2] AAUW. (1998). Separated by Sex: a critical look at single-sex education for girls. Washington, DC: 68-70.

[3] Bailey, S. (1992) How Schools Shortchange Girls: The AAUW Report. New York, NY: Marlowe \& Company.

[4] Bachman, K. R. O., Hebl, M.R., Martinez, L. R., Rittmayer, A.D. (2009). Girls' Exeriences in the Classroom: A Social Perspective. Rice University, Department of Psychology, Houston.

[5] Chapman, A. (2009). (n.d.). Gender Bias in Education: 160-167. From:

[6] http://www.edchange.org/multicultural/papers/genderbias.html

[7] Coffey, A. \& Delamont, S. (2000). Feminism and the classroom teacher: Research, Praxis and Pedagogy. Routledge Falmer, London: 19-20.

[8] Campbell P. B. \& Storo J. N. (1996) Girls Are... Boys Are...Myths, Stereotypes \& Gender Differences. Office of Educational Research and Improvement U.S. Claire, H. \& Holden, C. (2006). Gender and Citizenship Education. Produced by citized; Training and Development Agency for Schools.

[9] Dhamo, M. Sinani, M.Gjermeni, E. 2009. Perspektiva gjinore ne tekstet shkollore. Tiranë. PEGI: 12-42.

[10] Dhamo, M., Gjermeni. E, Sinani. M, Sulstarova. A, Sinani.J, Dauti. M. (2005). Analiza gjinore e teksteve të shkollës fillore. Botim i Qendrës "Aleanca Gjinore për Zhvillim". Tiranë: 14; 23-25; 35-36;

[11] ISHA. (2013). Udhëzues për Vlerësimin e Zbatimit të Edukimit Gjinor në Shkollë. ISHA \& Austrian Development Cooperation, Culture Contact Austria. Tiranë: 13-16.

[12] Kizilaslan, I. (2010). Student teachers' perceptions of gendered texts in English language Textbooks. Procedia Social and Behavioral Sciences (2): 3528-3531.

[13] Kabira, W. M. \& Masinjila, M. (1997). Abc of Gender Analysis. Forum for African Women Educationalists (FAWE). Layout by Midas Communications P0 Box 19757 Nairobi: 33-34.

[14] MAS. (2014). Standartet për tekstet shkollore. Tiranë: 50-54.

[15] Sinani M, Dhamo. M, Gjermeni E, Kalaja D. (2008). Përkatësia Gjinore në Tekstet Shkollore. Aleanca Gjinore për Zhvillim. Tiranë, Pegi: 17-25, 37-40.

[16] Sunderland, J. (2006). Language and gender. An advanced resource book. London.

[17] Sunderland, J., Cowley, M., Rahim, F. A., Leontzakou, CH., Shattuck, J. (2001). From Bias "In the Text" to "Teacher Talk Around the Text" An Exploration of Teacher Discourse and Gendered Foreign Language Textbook Texts. Linguistics and Education 11(3): 251- 286.

[18] Sadker, D., Sadker, M. (1994) Failing at Fairness: How Our Schools Cheat Girls. Toronto, ON: Simon \& Schuster Inc.: 284.

[19] Shel. T. A. (2007). Gender and Inequity in Education. Paper commissioned for the EFA Global Monitoring Report 2008, Education for All by 2015: will we make it? Pp: 9-12.

[20] UNESCO. 2003. Gender and Education for All: The Leap to Equality. EFA, Global Monitoring Report 2003-2004. Paris: UNESCO 
[21] Vu, A.P. (2008) Gender Stereotypes in Story Textbooks for Primary School Students in Vietnam. Oslo: Institute for Educational Research Faculty of Education.

[22] Zhupa, A. (2015). Gender Socialization in Albanian Schools: Reading the Texts, Listening to the Teachers. The International Journal of Humanities Education, Volume 13, Issue 2, pp.15-28 